\title{
Severe declines of Eastern Imperial Eagle Aquila heliaca populations in the Baikal region, Russia: a modern and historical perspective
}

\author{
VITALIY V. RYABTSEV and TODD E. KATZNER
}

\section{Summary}

The Eastern Imperial Eagle (Aquila heliaca), a vulnerable and declining species, is widely but sparsely distributed throughout its range. Because much of that range extends through the Russian-speaking world, relatively little on the species has been published in English. The world's easternmost population of Eastern Imperial Eagles, at Lake Baikal, Russia, is particularly well studied and, because of recent rapid population declines, is of great conservation concern. Here, using a data set covering more than 20 years evaluated in the context of historical accounts published in Russian, we assess recent severe declines in this population and the subsequent changes in its conservation status. In intensively surveyed areas near Lake Baikal, numbers of territories occupied by eagles have declined by $80-100 \%$ in the past $20-40$ years. Likewise, throughout the entire region, the average number of known occupied and breeding territories were both more than $40 \%$ lower in 1998-1999 than they were in 1982-1983. These data suggest severe long-term declines in the population of Baikal's Imperial Eagles. Because we observed only limited decreases in reproductive output, our interpretation of the patterns in these data is that mortality of non-breeding birds (wintering adults and all pre-adults) is the most likely cause for this decline. Addressing the causes of this decline is critical to protect this severely threatened population from extirpation.

\section{Резюме}

Восточный могильник (Aquila heliaca), уязвимый и сокращающийся в численности вид, широко, но разрозненно распространен по своему ареалу. В связи с тем, что большая часть его ареала находится в пределах русскоговорящей части мира, относительно мало опубликовано по этому виду на английском языке. Самая восточная группировка могильника находится в Прибайкалье. Она изучена особенно хорошо и из-за быстрого сокращения популяции вызывает особую тревогу и озабоченность природоохранников. Используя более чем >20 летние данные, рассмотренные в контексте исторических сведений опубликованных по-русски, мы оцениваем недавнее серьёзное сокращение этой популяции и последующие изменения в её природоохранном статусе. На территориях, находящихся под интенсивным обследованием в Прибайкалье, количество участков занятых орлами сократилось на 80-100\% за последние 20-40 лет. Таким же образом. во всем регионе. среднее 
количество известных занятых территорий и гнездовых участков в 1998-1999 было на $>40 \%$ меньше по сравнению с 1982-1983. Эти данные свидетельствуют о серьёзном долговременном сокращении прибайкальской популяции могильника. В связи с тем, что мы наблюдали лишь незначительное снижение результатов размножения, наша интерпретация модели по этим данным приводит к выводу, что смертность неразмножающихся птиц (зимующих взрослых и неполовозрелых птиц) является наиболее вероятной причиной этого сокращения. Выявление причин произошедшего падения численности очень важно для сохранения этой угрожаемой популяции от полного вымирания.

\section{Introduction}

The Eastern Imperial Eagle (Aquila heliaca) is a large generalist predator whose geographic range extends from western Europe into central Asia, north-western China and Siberia. The forest-steppe habitat it occupies reaches from the southern edge of Eurasia's deciduous forest and taiga to the northern edge of the great Asian deserts (Snow and Perrins 1998, Stepanyan 1990). While the biology of the closely related Spanish Imperial Eagle (Aquila adalberti) has been relatively well studied, the Eastern Imperial Eagle is generally poorly known and there are few published data on its demographics (exceptions include Danko and Chavko 1996, Bagyura et al. 2002, Bragin and Katzner 2004). Information on the population characteristics of the species is of particular importance because of its conservation status: its IUCN Red List status is Vulnerable (VU CI; IUCN 2002), it appears in the Bird Life International Red Data Book (BirdLife International 2001) and it is listed in the Red Data Book of the Russian Federation (DanilowDanilyan 2001).

The Imperial Eagles in the area of Lake Baikal in eastern Russia (including the Irkusk and Chita administrative regions and the Buryat Republic) are among the easternmost populations of this species (Figure 1). In this area Imperial Eagles are found between the upper reaches of the Angara River, $150-300 \mathrm{~km}$ from the city of Irkutsk, and the Onon River of the Chita Region (Vasilchenko 1986, Golovushkin and Osipova 1988, Stepanyan 1990). The eastern border of the range corresponds with the eastern edge of the distribution of the Siberian Ground Squirrel (Spermophilus undulatus), which is the primary prey of Baikal's Imperial Eagles (Ryabtsev 1999a). To the south, the distribution of the species extends into northern Mongolia, albeit apparently at relatively low population densities (Heidecke et al. 1992, Boldavatar 2003). The Baikal population of Imperial Eagles is also geographically isolated - it is at least $600 \mathrm{~km}$ east of the nearest known population in Russia, found near the Minusinskaya depression, south of Krasnoyarskiy Krai (Krasnoyarsk administrative division). During Soviet times the Baikal population of Imperial Eagles was also one of the best studied populations in the world (Skalon 1934, Sonin 1969, Sonin and Lipin 1980, Ryabtsev 1984, 1989, 1999a, b, 2000). However, most of that literature is in Russian and remains inaccessible to non-Russianspeakers.

In addition to being well studied, the Baikal population of Imperial Eagles was, only two decades ago, one of the largest such populations in Russia. However, in recent years it has declined dramatically in size and it is now extremely small, fragmented and highly threatened (Ryabtsev 1999b). Other populations in Russia have not shown similar declines; most were stable and some, such as those in the Ural region and the Lower Povolgye river region, have even been increasing (Belik and Galushin 1999, Karyakin 1999).

This study was designed to evaluate the decline in Imperial Eagles in the Baikal region. Specifically, we (a) use demographic data collected over the past 20 years to describe the 


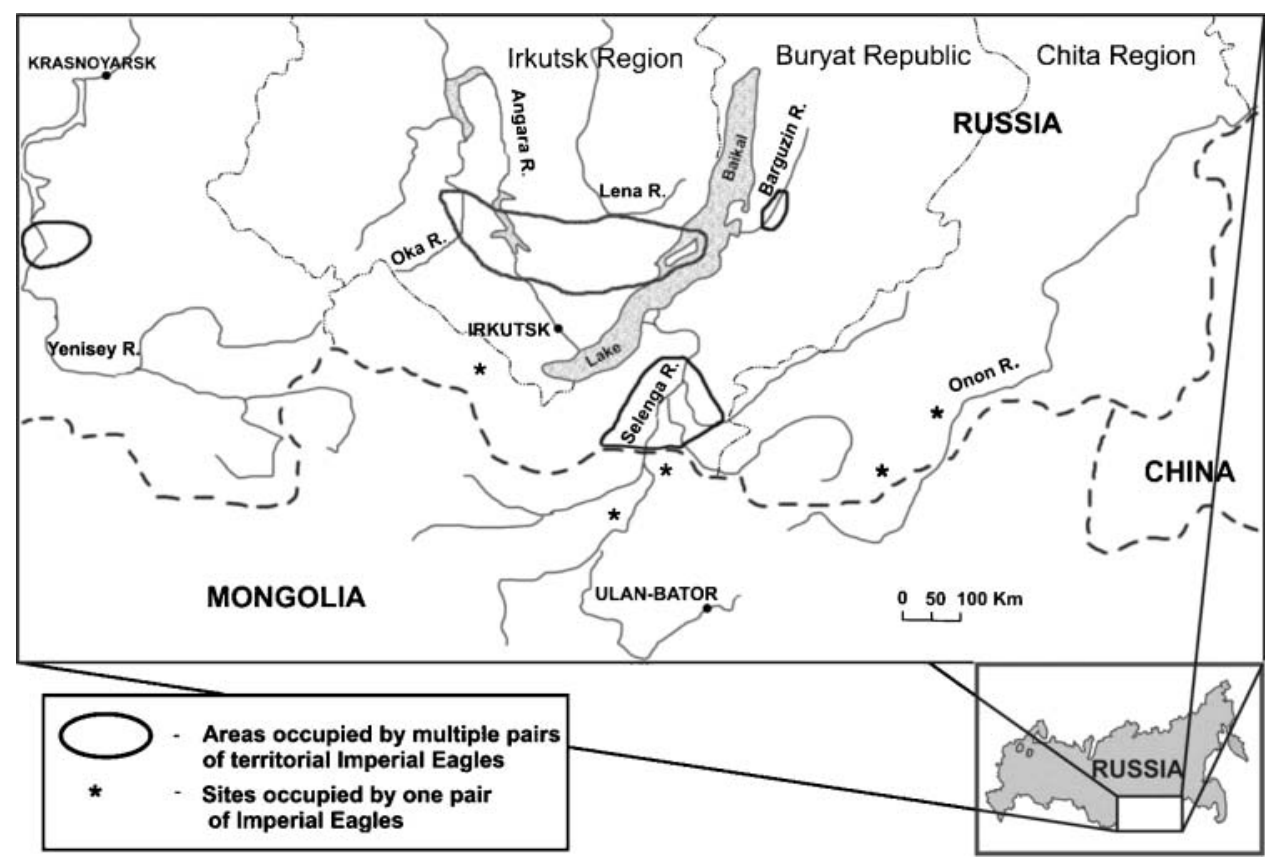

Figure 1. Map of Russia showing the Baikal area and the areas occupied by Imperial Eagles in and around Lake Baikal. The large central area including Olkhon Island and areas west of Lake Baikal is referred to as 'western Pribaikalye'.

trajectory and magnitude of recent population changes; (b) put these data in the context of historical trends, using data published in the past 50 years and anecdotal information from previous centuries; and (c) evaluate these trends in the context of threats facing the eagles and suggest potential measures for their conservation.

\section{Study area and species biology}

\section{Study area}

This research was conducted west of Lake Baikal in the western part of the Baikal administrative region of Russia ('western Pribaikalye'). Climate here is severe and continental; average annual temperatures range from about $-3.3{ }^{\circ} \mathrm{C}$ to $0.7{ }^{\circ} \mathrm{C}$ and average precipitation varies from 101 to $423 \mathrm{~mm}$. Local topography is generally flat, being composed of broad river valleys with terraced sides. Elevation averages about $650 \mathrm{~m}$ above sea level, and ranges from 300 to $1000 \mathrm{~m}$ (Boyarkin 1985). The surface of Lake Baikal is $456 \mathrm{~m}$ in elevation. Habitat in western Pribaikalye includes forest, forest-steppe and wetlands. River valleys are composed of wet meadows, bogs and marshes. River terraces and warmer valley slopes are most often covered by steppe vegetation. These steppe landscapes, which are located in the south-eastern and central parts of western Pribaikalye, are disconnected and fragmented by both natural and anthropogenic processes.

Forests, which cover just over half the region, are primarily coniferous, with pine (Pinus sylvestris) on flat terrace bottoms and south- and west-facing slopes and larch (Larix sibirica) on north-facing slopes. Local steppe habitats are relicts of dry Mongolian grasslands that once extended throughout Siberia. Currently this habitat is composed of several different types of steppes including grasslands (dominated by Stipa spp. and Festuca spp.), shrub-steppes 
(primarily Artemisia spp.), wet meadows (of Calamagrostis spp., Bromopsis spp., Agrostis spp. and Elytrigia spp.) and mountain-steppe (dominated by Festuca spp., Thymus spp., Oxytropis spp. and Chamaerhodos altaica). Steppes of the basin of Lake Baikal are unique among these relicts in that their vegetation is composed primarily of legumes (e.g. Oxytropis spp., Hedysarum spp. and Astragalus spp.).

Because of the complicated relief of the area, only $30-50 \%$ of the western Pribaikalye steppe has been ploughed (this is considerably less than in some other agricultural areas of the former Soviet Union; Katzner et al. 2003, V. Ryabtsev, pers. obs.). Since the break-up of the Soviet Union, the area used for agriculture has been reduced by about $50-75 \%$ and grazing by domestic livestock, primarily cattle, has decreased by approximately 80-90\% (V. Ryabtsev, pers. obs.). However, because planting is rotated among fields, recolonization by native flora of farmed habitats is slow.

Within the Baikal Basin itself, less than $10 \%$ of the steppe was ploughed before 1980 and even less is currently used. Further protection was afforded in 1986, when nearly all these Baikal Basin steppe lands (112,00o ha) were included in the newly created Pribaikalsky National Park, which has a total area of 417,300 ha. At present the greatest changes to the local steppe are the result of decreased grazing pressure, which increases the height of vegetation. Forested habitats are threatened primarily by fires.

\section{Imperial Eagle biology}

Imperial Eagles in the western Pribaikalye inhabit parts of the forest-steppe of the Lena-Angarsk plateau, areas near the Bratsk Reservoir and parts of the Ziminsko-Kutunsky region, all west of Lake Baikal, and Olkhon Island in the lake itself (Figure 2). They usually breed in pine or larch trees (nest height range 7-22 $\mathrm{m}$ ) that are either in open steppe or near the edge of forest patches. Nest-sites are usually located near steppe inhabited by ground squirrels (Ryabtsev 1999a).

This Eastern Imperial Eagle population is migratory, and birds generally return to western Pribaikalye at the end of March or beginning of April. Eggs are laid in mid- to late April or early May and nestlings hatch in late May to mid-June; fledging occurs in early to mid-August (Ryabtsev 1999a). The most heavily used prey is Siberian Ground Squirrel, but birds (Northern Lapwings Vanellus vanellus and corvids Corvus spp.) are also taken regularly. Southbound migration begins in late September or early October. Satellite-tracked Imperial Eagles from this region have wintered in China, on the Yunnan plateau and surrounding mountain ridges of Yunnan province, and in adjoining parts of eastern Burma and northern Thailand (Ueta and Ryabtsev 2001).

The habitat occupied by Baikal's Imperial Eagles coincides with traditional areas used by native Buryat tribes, historically a herding and agricultural people. The steppe their cattle grazed provided the best local habitat for ground squirrels, and the "White-headed Eagle", which is said to have occurred at extremely high densities on Olkhon Island, plays an important role in Buryat mythology and some shaman ceremonies (Manzhigeev 1978). As a consequence, the species has not been persecuted in this area, and in the 1980s and 1990s Imperial Eagles often lived less than $\mathrm{I} \mathrm{km}$ from inhabited villages and cattle farms.

\section{Materials and methods}

Imperial Eagles in western Pribaikalye were studied between 1978 and 2004. Research effort, which was not consistent throughout this period, was determined by logistical and financial constraints. Data collection was particularly detailed in two periods: 1981-1983 and 1998-1999. Less intensive data collection also occurred in 1978-1979, 1984, 1988, 1990-1993, 1996-1997 and 2000-2004. Data collection occurred at two spatial scales with focused study on two intensively monitored study areas (near the villages of Tangut $\left[53^{\circ} 45^{\prime} \mathrm{N}, 102^{\circ} 4 \mathrm{O}^{\prime} \mathrm{E}\right]$ and Sarma $\left[53^{\circ} \mathrm{O} 5^{\prime} \mathrm{N}, 106^{\circ} 5 \mathrm{O}^{\prime} \mathrm{E}\right]$ ) and more general surveys throughout the entire region (Figure 2). We 


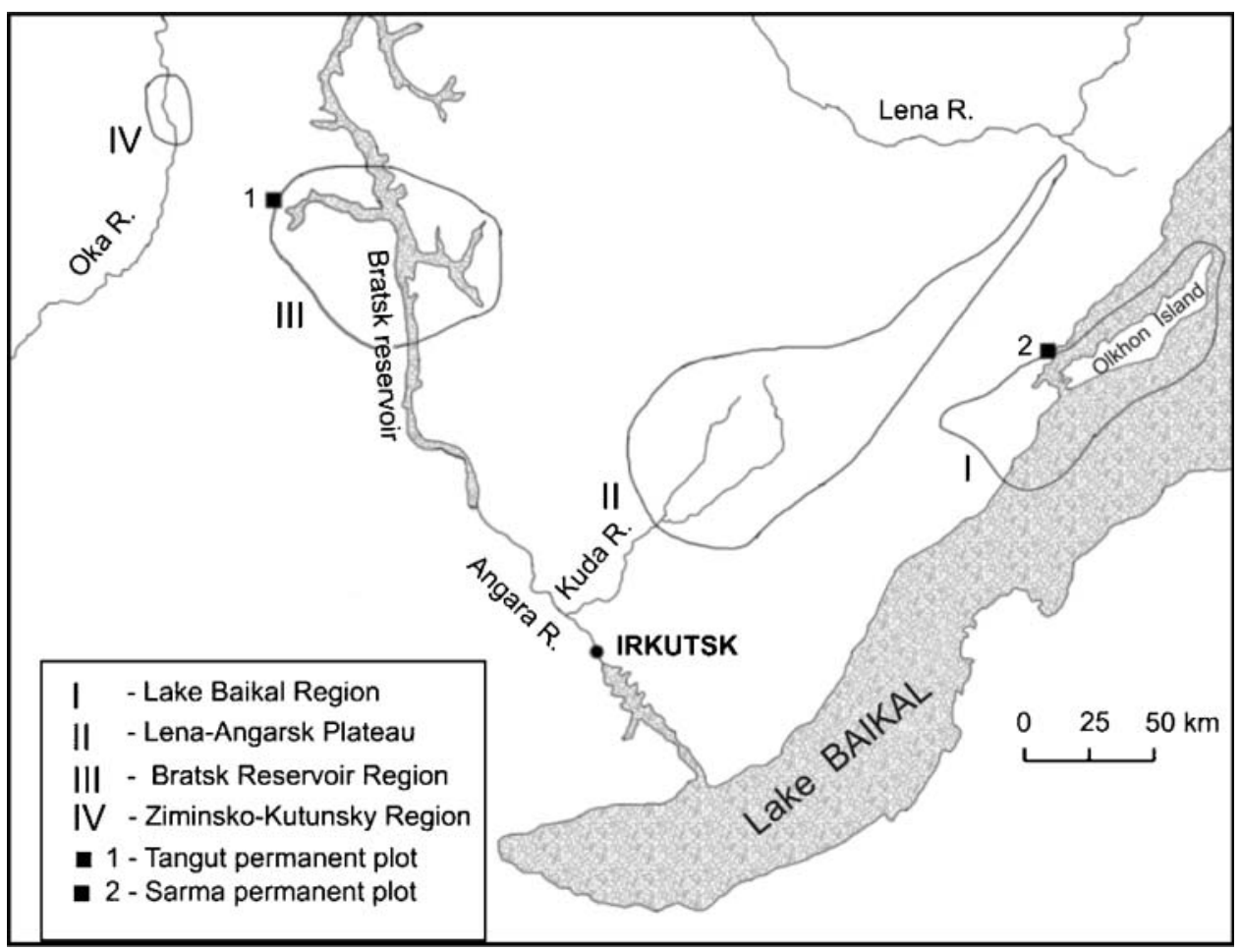

Figure 2. Detail of the study area showing the entire western Pribaikalye region - from the Oka river through Lake Baikal. Regions I, II, III and IV correspond to areas where vehicle, walking and observational surveys were conducted. Tangut (1) and Sarma (2) were the sites of intensively monitored plots.

also compare our data with those from the westernmost population of Baikal's Imperial Eagles, in the Ziminsko-Kutunsky region (Fefelov 2003).

Nesting behaviour (chronology, density, fecundity) of eagles was closely monitored in the two intensively studied plots from 1981 to 1983 . The first and larger of these study areas covered 60 $\mathrm{km}^{2}$ and was located to the west of the Bratsk Reservoir, near the village of Tangut. About 20 $\mathrm{km}^{2}$ of this plot was forested. The second of these study areas covered $30 \mathrm{~km}^{2}$ on the western coast of Lake Baikal, near the village of Sarma; about $10 \mathrm{~km}^{2}$ of this area was forested (Figure 2). During these studies, nest-searching was conducted by a single observer on foot. The Tangut area was searched for 131 days between April and August over a 3-year period, 1981-1983. The Sarma area was searched for 32 days in May-June of $1982-1983$ and again for 14 days in 1996 and 15 days in 1999. Nests were climbed late in the breeding cycle to minimize disturbance, reproductive output was verified and chicks were banded with aluminium rings.

Encounter rates of individual eagles (indicators of relative density) were monitored in these same two areas in 1981-1983, 1996 and 1999. On these surveys a single observer (V. Ryabtsev) on foot counted all birds observed from May through June. In total, surveys covered $1667 \mathrm{~km}$ and lasted 632 hours. Encounter rates for each region were calculated separately for open habitats (steppe, agricultural fields, etc.) and for forested habitats. These surveys are not useful for indicating population density, but they can provide a mechanism for comparing relative densities among regions (Neronov 1962). In this case these surveys were particularly appropriate because they could be compared with data collected by Sonin, who used the same technique in 1959-1965 (Sonin 1969). 
A considerable area of the western Pribaikal region outside these study plots was searched from four-wheel drive vehicles during the breeding seasons in $1981-1983$ (covering about 4,000 $\mathrm{km}$ in this period), in $1998(4,760 \mathrm{~km})$ and in $1999(6,050 \mathrm{~km})$. Observations, which were focused on areas I-III in Figure 2, were also made from roads and hilltops. Because the local network of unpaved roads is dense and because eagles are highly visible in this area, it is likely that a large proportion of the nesting pairs in the area were identified.

To understand our results in the context of historical trends, we also evaluated all previously published reports on Imperial Eagles of the Baikal region (Skalon 1934, Sonin, 1969, Sonin and Lipin 1980). We used standard parametric and non-parametric statistics ( $t$-tests, Mann-Whitney test and Kruskal-Wallis tests) to compare demographic statistics among regions and time periods.

\section{Results}

\section{Historical data}

As was noted previously, local mythology suggests historically high densities of Imperial Eagles, particularly on Olkholn Island (Manzhigeev 1978). There is almost no information about the number of Imperial Eagles in the Baikal region in the first part of the 190os; only Skalon (1934) comments on high densities of eagles. In the 1950s and 1960s, walking surveys in open habitats during migration (April, May and September) covered $156 \mathrm{~km}$ (52 hours) and 64 eagles were encountered (an average of 1.23 birds per hour; Sonin 1969). In 1964 in $20 \mathrm{~km}^{2}$ of the Tangut study area, nearest-neighbour distances among the five known Imperial Eagle nests were 1.5-2 $\mathrm{km}$ (Sonin and Lipin 1980).

\section{Population dynamics}

\section{Bratsk Reservoir region}

From 1981 to 1983 , and again in more recent years, Imperial Eagles were studied in the same 20 $\mathrm{km}^{2}$ study area near Tangut where Sonin (1969) carried out his studies. The number of territorial pairs was always less than Sonin observed and declined over the period of this study (Table 1). In 1981-1982 nearest-neighbour distances of 2-5 km between the nests of the 4 pairs in this forest were greater than those reported from the 1960 .

In 1981-1984 walking surveys in and around the study area near Tangut covered $808 \mathrm{~km} \mathrm{(333}$ hours) and 64 eagles were encountered. Hourly encounter rates were also less than in the 196os. In open habitats in April and May (64 hours of observation during migration) 0.17 eagles were seen per hour of observation, and from the middle of June to the beginning of August (66.5 breeding season hours) 0.47 birds were seen per hour.

Table 1 . Number of territorial pairs of Imperial Eagles in three closely monitored areas near Lake Baikal, Russia.

\begin{tabular}{lllll}
\hline Region & 1964 & $1981-1983$ & $1998-1999$ & 2004 \\
\hline Tangut region (Bratsk Reservoir) & 8 & $3-4$ & 1 & - \\
Olkhon & $12-15$ & 6 & 2 & 0 \\
Priolkhonye (near Sarma) & - & 10 & 3 & 2 \\
\hline
\end{tabular}

Tangut data from 1964 are from Sonin and Lipin (1980). Olkhon data from 1964 are extrapolated based on the number of old (unoccupied) nests observed in later years. The Priolkhonye area was not searched in 1964 and Tangut was not searched in 2004 . 


\section{Lake Baikal region}

At and around Lake Baikal, Imperial Eagles inhabit only the forest-steppe of Baikal's western coast (Priolkhonye) and the forest-steppes of Olkhon Island. Olkhon has dense forest, the northern half is roadless and eagle densities are low, making it difficult to survey for birds there. Altogether in 1982-1983, 1990, 1993, 1996 and 1999 walking surveys in Priolkhonye and Olkhon covered $869.3 \mathrm{~km}$ (299 hours) but only 25 eagles were encountered (0.08 birds per hour).

The number of territories on Olkhon Island decreased over the course of the study until this subpopulation was extirpated (Table 1). In 1982-1983 nests were found at four of the Imperial Eagle territories in the southern part the island. Additionally, a large number $(\sim 20)$ of inactive nests were found, most spaced at $1.5^{-2} \mathrm{~km}$ intervals. Since individual territories of Baikal's eagles usually have $1-3$ nests that are $0.05-2 \mathrm{~km}$ apart, the number and spacing of inactive nests provides a rough indicator of past eagle densities. By extrapolating from densities of abandoned nests we estimate that there were once at least $12-15$ pairs of eagles on Olkhon. This implies breeding populations at least 2 to 2.5 times greater than in the early 1980 s and suggests that the declines we report here have been ongoing for many years.

The number of territorial Imperial Eagles in the Priolkhonye area near Sarma also declined dramatically over the course of this study, from a high of 10 in the early 1980 os to a current low of 2 (Table 1 ). We have no historical data on the number of eagle territories there.

The total number of confirmed breeding pairs at and around Lake Baikal declined from an average of 15.5 in $1982-1983$ to 4.25 in 1993,1996 and $1998-1999$, to 2.5 in 2003-2004. Differences among these periods were statistically significant (Kruskal-Wallis test, $H_{\text {adj }}=15.35$, $P<0.02)$.

\section{The entire Western Pribaikalye}

In 1978-1983 during vehicle and walking surveys throughout the entire Western Pribaikalye (excluding the Ziminsko-Kutunsky forests), 36 pairs of imperial eagles were observed. In 20 cases breeding was observed at nests; breeding status of the other 16 pairs was not confirmed. Nesting density of these birds ranged from 5 pairs $100 \mathrm{~km}^{-2}$ in at the interface between large forest patches and steppe, to 2 pairs $100 \mathrm{~km}^{-2}$ in steppe areas with little forest, to only 0.25 pairs $100 \mathrm{~km}^{-2}$ in areas used for agriculture.

In 1998-1999 vehicle surveys were repeated throughout the entire western part of Baikal region and all nests and nest-sites that had been found in 1978-1983 were examined again. Of the 21 territories that were previously known to be active, only 5 remained active, but an additional 7 new territories were found. At these 12 occupied territories we observed 17 breeding attempts (breeding occurred in both years at 5 territories). Further examination of these same territories in 2003-2004 suggests that at least 5 of the 12 had been abandoned.

\section{The Ziminsko-Kutunsky region}

The westernmost nesting group of the Baikal Imperial Eagle population inhabits the ZiminskoKutunsky forest-steppe region (total area about $2500 \mathrm{~km}^{2}$ ) and has been quite stable in recent years. Between 1998 and 2004, 4-6 pairs continuously occupied territories here, most in a 400 $\mathrm{km}^{2}$ valley of the Oka River (Fefelov 2003).

\section{Fecundity and nesting success}

\section{Bratsk Reservoir region}

In $1978-1983,14(56 \%)$ of the 25 monitored nesting attempts were successful (Table 2). Of the 9 nests examined in 1981-1983, 7 contained two eggs, I contained one egg and 1 contained three 
eggs (mean $[ \pm S D]$ number of eggs $=2.0 \pm 0.47$ ). In 1980 one nest was found with four eggs, three of which were infertile (Popov 1984). On average 1.0 \pm 1.04 chicks were produced per nest studied.

Nest failure could be attributed to one of several known factors. These included weather $(n=$ 1 nest), corvid predation $(n=1)$, abandonment apparently from ant infestation $(n=1)$, unhatched eggs ( $n=4$; note that unhatched eggs also occurred in successful nests) and chick death from unknown causes $(n=1)$. In 3 cases eggs were not laid, despite observation of repeated copulation. At the 19 nests where incubation occurred, 12 unhatched eggs were found (o.63 unhatched eggs per clutch). Nine of these 12 eggs were opened; eight were unfertilized and one contained a dead embryo.

Shell thickness of nine eggs in museum collections (from Moscow and Irkusk) and nine unhatched eggs collected between 1981 and 1983 (from the Bratsk Reservoir and Lake Baikal areas) was measured with Ratcliffe's (1967) index. In a single case the eggshell of one unhatched local egg was significantly (12.5\%) thinner than average; the same clutch also contained an egg with a dead embryo and an unusually thick shell (Ryabtsev 1989).

\section{Lake Baikal region}

In $1978-1983,13(93 \%)$ of the 14 observed nesting attempts were successful (Table 2). The one nest failure was most likely due to disturbance, since this nest was built near a road and abandoned at the egg stage. On average $1.42 \pm 0.85$ chicks were produced per studied nest.

The number of defective eggs per nest in the Baikal region appeared lower than at the Bratsk Reservoir. The 13 successful nests in this period contained only two unfertilized eggs and a third with a dead embryo ( 0.23 unhatched eggs per incubated clutch; excluding the one disturbed nest, all nests hatched at least one egg). In spite of the lower frequency of unhatched eggs in this region, the average $( \pm S D)$ number of fledglings at successful nests, $1.81 \pm 0.75$, was not significantly different between the two sites $(U=126.5, P>0.05$; Ryabtsev, 1989). Higher fecundity near the Bratsk Reservoir may be related to the apparently greater densities of ground squirrel prey in this area (Ryabtsev, unpubl. obs.).

Insecticides were rarely used in the Baikal region in 1982-1983 and such chemicals have not been used there at all since the end of the 1980s. Nevertheless, analysis of an egg collected in 1998 revealed the presence of DDE (100 ng/g) and PCBs (50 ng/g; D. Tillitt, pers. comm.) that may have influenced reproductive success.

\section{The entire Western Pribaikalye}

In 6 years of observations between 1979 and 1984, 29 of 41 observed nesting attempts were successful (71\%) and in 5 years of observations between 1993 and 1999 (no data 1994-1995), 13 of 25 observed nesting attempts were successful $(52 \%)$. Success rates in these periods were not significantly different $\left(\chi^{2}=1.61, P>0.05\right)$. In 1993 failure of all three nests observed may have been due to an epizootic plague in the ground squirrel population (Ryabtsev 1995).

Table 2. Nesting success of Imperial Eagles in two closely monitored areas near Lake Baikal, Russia.

\begin{tabular}{|c|c|c|c|c|c|}
\hline Region & $\begin{array}{l}\text { No. of nesting } \\
\text { attempts } \\
\text { monitored }\end{array}$ & $\begin{array}{l}\text { No. of } \\
\text { incubated } \\
\text { clutches }\end{array}$ & $\begin{array}{l}\text { No. of } \\
\text { successful } \\
\text { attempts }\end{array}$ & $\begin{array}{l}\text { No. of unhatched } \\
\text { eggs per incubated } \\
\text { clutch }\end{array}$ & $\begin{array}{l}\text { No. of fledglings per } \\
\text { successful attempt }\end{array}$ \\
\hline \multirow{2}{*}{$\begin{array}{l}\text { Bratsk Reservoir } \\
\text { Lake Baikal }\end{array}$} & 25 & 19 & 14 & $0.63 \pm 0.11$ & $1.79 \pm 0.70$ \\
\hline & 14 & 13 & 13 & $0.23 \pm 0.12$ & $1.54 \pm 0.78$ \\
\hline
\end{tabular}

Data are from the period $1978-1983$ and data per nesting attempt are means \pm SD. 
Between 1984 and 2004 nests were visited irregularly and the reasons for nest failure are poorly known. Generally, unsuccessful nests contained dried pine and larch branches and fragments of eggshell, suggesting that these nesting attempts failed at the egg stage.

Altogether in the western part of the Baikal region between 1978 and 1983 there were on average $1.1 \pm 0.05( \pm$ SE) fledglings per nesting pair per year and $1.53 \pm 0.17$ fledglings per successful pair. Between 1996 and 1999, there were $1.02 \pm 0.12$ fledglings per nesting pair per year and $1.70 \pm 0.17$ fledglings per successful pair. The difference in average productivity per pair and productivity per successful pair between these two periods is not statistically significant $(t=0.46, P>0.05 ; t=0.50, P>0.05)$.

Because sampling efforts in these 5 -year periods were not equivalent, we also considered two 2-year periods, 1982-1983 and 1998-1999, during which sampling effort was almost identical. In contrast to the 5-year trends, these data show clear decreases with time in the average number of occupied and breeding territories ( $48 \%$ and $41 \%$ decreases, respectively; Table 3 ). Success rates and number of chicks produced at those territories also appear to decline, but these declines are less well defined.

\section{The Ziminsko-Kuytunsky region}

In Ziminsko-Kutunsky forest-steppe region in 1998-2003, the number of successful nests was relatively high. Fefelov (2003, unpubl. obs.) reported 1.33 fledglings per nesting pair and 1.54 fledglings per successfully nesting pair.

\section{Discussion}

Although intermittently collected, the data we present span a long time period ( $>25$ years) and, in concert with the historical data, suggest long-term declines in the population of Imperial Eagles in and around Lake Baikal. Furthermore, these declines appear to have occurred across nearly the entire landscape and are manifested primarily by decreases in the number of territorial and nesting pairs and secondarily by decreases in nesting output.

Several authors have estimated regional densities of Imperial Eagles based on extrapolations from focal study plots to the entire Baikal region (including the Ziminsko-Kutunsky region). Although these estimates do not allow us to make statistically rigorous population estimates, they do provide insight into the likely scale of the population declines these eagles have experienced. Early estimates of the Imperial Eagle population in Baikal from Sonin (1969) and Ryabtsev (unpubl. obs. on the number of abandoned nests in the region) suggest that there were about 300 pairs of eagles in the Irkusk region in the 1960s (Ryabtsev 2000). By the beginning of the 1980 s similar extrapolations suggest a population of $150-200$ pairs, by 1999 about 40 pairs,

Table 3. Data on nests of Imperial Eagles from the entire Irkutsk region near Lake Baikal, Russia from a 2year period in the early 1980 and a 2 -year period in the late 1990 .

\begin{tabular}{lllllllll}
\hline Year & $\begin{array}{l}\text { Occupied } \\
\text { territories } \\
\text { observed }\end{array}$ & $\begin{array}{l}\text { Breeding } \\
\text { attempts } \\
\text { monitored }\end{array}$ & $\begin{array}{l}\text { Nests } \\
\text { with one } \\
\text { fledgling }\end{array}$ & $\begin{array}{l}\text { Nests } \\
\text { with two } \\
\text { fledglings }\end{array}$ & $\begin{array}{l}\text { Nests } \\
\text { with three } \\
\text { fledglings }\end{array}$ & $\begin{array}{l}\text { Success } \\
\text { rate }\end{array}$ & $\begin{array}{l}\text { Fledglings Fledglings } \\
\text { per nest } \\
\text { (av.) }\end{array}$ & $\begin{array}{l}\text { per } \\
\text { successful } \\
\text { nest (av.) }\end{array}$ \\
\hline 1982 & 21 & 17 & 6 & 3 & 3 & 0.71 & 1.24 & 1.75 \\
1983 & 16 & 12 & 4 & 4 & 1 & 0.75 & 1.25 & 1.67 \\
1998 & 10 & 9 & 3 & 3 & 0 & 0.67 & 0.90 & 1.5 \\
1999 & 9 & 8 & 0 & 3 & 0 & 0.38 & 0.54 & 2 \\
\hline
\end{tabular}

Sampling effort during the two periods was similar. Data are presented for each year of the study, as totals or averages, as appropriate. 
and by 2005, 25-30 pairs (Ryabtsev 1999b, unpubl. obs.). Although statistical comparison of these estimates is impossible, there are two noteworthy trends in these data. First, this long-term decline appears to have accelerated in recent years. Second, this decline was observed in all populations except those in the Ziminsko-Kutunsky forest-steppe region. Since most of the steppe in the Ziminsko-Kutunsky region has been ploughed, the prey base seems smaller and outward appearances suggest that it should be less suitable habitat than many other places where populations have not remained stable.

The population declines we report could be due to one or more of a number of possible causes, including ( 1 ) increased breeding season mortality (by persecution or poisoning), (2) decreased breeding success or (3) increased non-breeding mortality (pre-adults and adults on migration and wintering grounds). Although we have few data on mortality rates during the breeding season, we believe that it is likely they are low and that it is unlikely they have changed over the past 30 years. Indigenous Buryats hold eagles in high esteem and do not persecute them, and other local peoples rarely harass or kill eagles. Additionally, as we have noted, pesticide use in the Baikal region has never been particularly high and has actually declined in recent years.

We observed small but potentially important declines in reproductive output by eagles over the period of this study. These declines are especially notable because the decrease in population size would presumably relieve any previously operating density-dependent effects. Fecundity of eagles such as these can be influenced by a few possible factors. These include changes in the prey base, changes in levels of environmental pollutants, or changes in the average age of breeding eagles. Prey populations in the western Pribaikalye appear to be relatively stable (Ryabtsev, unpubl. obs.), but there are few quantitative data on their status. However, changes in grazing regimes, such as those which have been observed in this region, have affected ground squirrel densities in other areas (E. Bragin, unpubl. obs.). Pesticide use in the area of Lake Baikal has actually declined since the break-up of the Soviet Union and appears unlikely to be a negative influence on eagle demography. Furthermore, if changes in prey base or local pesticide use were highly significant, these should also affect other predators, nearly all of whose populations are either stable or increasing (only Saker Falcon Falco cherrug populations have declined and this is due to illegal harvest; Ryabtsev 2001a, b). Eagles may, however, acquire pesticide loads when on their wintering grounds, and increases in mortality of adults would decrease the age of breeding eagles, which may affect fecundity (Ferrer and Bisson 2003).

Changes in breeding output alone do not appear to explain a great deal of the decline in Baikal's Imperial Eagles. For this reason we believe that increased mortality of and exposure to pesticides by wintering birds may be the best explanations for population decline that we have identified here. Three additional lines of evidence support this explanation. First, as was noted earlier, Imperial Eagles from Baikal are apparently the only population of this species that winter in South-East Asia. All other Imperial Eagle populations from the former Soviet Union are thought to winter between south-central Asia and the Arabian Peninsula (T. E. Katzner, unpubl. obs., Meyburg et al. 1996), and these populations are all apparently more stable than are Baikal's. Second, South-East Asia is an area that has undergone massive economic growth in the past 30 years. This growth has been accompanied by an increase in human population size, pesticide use and rates of habitat loss, all factors that can influence mortality rates of raptors (Zalles and Bildstein 2000). Finally, recent simulation modelling of Imperial Eagles in Kazakhstan suggests that long-term changes in productivity can affect population size slowly, but that only increased mortality can explain faster declines of the type we have observed in the past 15 years at Baikal (Katzner et al. 2006). These three factors together do not provide a causative explanation for the decline of the Baikal Imperial Eagle population, but they do suggest correlative patterns that deserve further investigation.

The future of the Baikal Imperial Eagle population is severely threatened with extirpation. Our data on population declines and the correlative evidence we provide suggest that these declines may be driven by a number of different factors. The conservation of this special population may therefore depend on measures designed to evaluate causes of threats that these 
eagles face and to develop mitigation for them. Research into these declines is therefore essential. Our data suggest that this research should focus specifically on (a) non-breeding behaviour of pre-adults and adults (including satellite telemetry and winter surveys); (b) the impact of habitat change on breeding success; and (c) pesticide and other toxin levels in birds and eggs.

\section{Acknowledgements}

The vast majority of these data were collected by V. V. R., who was, in the early years, supported by the Soviet Government, and more recently by the U.S. Agency for International Development, the Wild Bird Society of Japan, the John D. and Catherine T. MacArthur Foundation, and the Wildlife Conservation Society. T. E. K. was supported by a U.S. National Science Foundation International Postdoctoral Research Fellowship (INT-0301905). Imperial College London and the Pribaikalsky National Park provided institutional and logistical support for this project. P. A. Vagin, I. V. Fefelov and E. A. Bragin assisted with translation of these materials from Russian to English. Yevgeni Shergalin translated the abstract into Russian. E. J. Milner-Gulland, Jeff Watson and Marton Horvath provided careful reviews that greatly improved the quality of the manuscript.

\section{References}

Bagyura, J., Szitta, T., Haraszthy, L., Firmánszky, G., Viszló, L., Kovács, A., Demeter, I. and Horváth, M. (2002) Population increase of Imperial Eagle (Aquila heliaca) in Hungary between 1980 and 2000. Aquila 107-108: 133-144.

Belik, V. P. and Galushin, V. M. (1999) Population structure of Imperial Eagle (Aquila heliaca) habitat in Northern Eurasia. Imperial Eagle: distribution, status of populations and prospects of protection Imperial Eagle (Aquila heliaca) in Russia. Rare Birds Series 1: 129-139 [in Russian].

BirdLife International (2001) Threatened birds of Asia: The BirdLife International Red Data Book. Cambridge, U.K.: BirdLife International.

Boldavatar, S. (2003) Birds of the Eg river basin. Ornithological Research in Siberia and Mongolia 3: 6-17 [in Russian].

Boyarkin, V. M. (1985) Geography of Irkutsk Region. Irkutsk: Irkutsk University Press [in Russian].

Bragin, E. and Katzner, T. (2004) Long-term population trends and nesting success of Imperial Eagle, Golden Eagle and Whitetailed Sea Eagle in north-west Kazakhstan in 1990-2002. Pp. 551-556 in R. D. Chancellor and B.-U. Meyburg, eds.
Raptors worldwide: Proceedings of the VI World Conference on Birds of Prey and Owls. Budapest: WWGBP/MME BirdLife Hungary.

Danko, S. and Chavko, J. (1996) Breeding of the Imperial Eagle Aquila heliaca in Slovakia. Pp. 415-423 in B.-U. Meyburg and R. D. Chancellor, eds. Eagle studies. Berlin: World Working Group on Birds of Prey.

Danilow-Danilyan, V. I., ed. (2001) Red Data Book of the Russian Federation (animals). Moscow: Astrel Press [in Russian].

Fefelov, I. V. (2003) Imperial Eagle (Aquila heliaca) in Ziminsko-Kuytunsky region of Pre-Angara forest-steppe. Ornithological Researches in Siberia and Mongolia 3: 194-203 [in Russian].

Ferrer, M. and Bisson, I. (2003) Age and territory-quality effects on fecundity in the Spanish imperial eagle (Aquila adalberti). Auk 120: 180-186.

Golovushkin, M. I. and Osipova, M. A. (1988) Nesting of the Imperial Eagle in Zabaikalye. Ornithology 23: 205-206 [in Russian].

Heidecke, D., Stubbe, M., Sumjaa, D., Samjaa, R. and Ansorge, H. (1992) First records of some bird species of Mongolia. P. 55 in Internationales Symposium 
Erforschung biologischer Ressourcen der Mongolei: Thesen der wissenschaftlichen Beitrage. Halle-Wittenberg: MartinLuther-Universität and Ulan-Bator: Mongolische Staatliche Universität.

IUCN (2002) 2002 IUCN Red List of threatened species. http://www.redlist.org (accessed 20 December 2004).

Karyakin, I. V. (1999) Imperial Eagle in Ural region. Imperial Eagle: distribution, status of populations and prospects of protection Imperial Eagle (Aquila heliaca) in Russia, Rare Birds Series 1: 41-53 [in Russian].

Katzner, T. E., Bragin, E. A., Knick, S. T. and Smith, A. T. (2003) Coexistence in a multispecies assemblage of eagles in Central Asia. Condor 105: 538-551.

Katzner, T., Milner-Gulland, E. J. and Bragin, E. (2006) Using modeling to improve monitoring of structured populations: are we collecting the right data? Conserv. Biol. 21: $241-252$.

Manzhigeev, I. A. (1978) Buryat's shaman and pre-shaman terms. Moscow: Nauka Press [in Russian].

Meyburg, B.-U., Meyburg, C., Scheller, W. and Paillat, P. (1996) Satellite tracking of eagles: method, technical progress and first personal experiences. Pp. 529-549 in B. -U. Meyburg and R. D. Chancellor, eds. Eagle studies. Berlin: World Working Group on Birds of Prey.

Neronov, V. M. (1962) Applying a method of simple registration for relative count of birds of prey. Ornithology 5: 386-392 [in Russian].

Popov, V. V. (1984) Interesting finding of Imperial Eagle's nest in Pre-Baikal region. Ornithology 19: 185 [in Russian].

Ratcliffe, D. A. (1967) Decrease in eggshell weight in certain birds of prey. Nature 215: 208-210.

Ryabtsev, V. V. (1984) Ecology and conservation of Imperial Eagle (Aquila heliaca) in Pre-Baikal region. Leningrad State University Newsletter 9: 20-27 [in Russian].

Ryabtsev, V. V. (1989) About factors affecting Imperial Eagle reproductive success in the Pre-Baikal region. Ecology 5: 63-67 [in Russian].

Ryabtsev, V. V. (1995) Status of rare populations in Priolkhonye (Baikal).
Moscow Society of Naturalists' Newsletter 2: 40-45 [in Russian].

Ryabtsev, V. V. (1999a) Ecology of Imperial Eagle in Baikal region. Imperial Eagle: Distribution, status of populations and prospects of protection Imperial Eagle (Aquila heliaca) in Russia. Rare birds series 1: 122-128 [in Russian].

Ryabtsev, V. V. (1999b) Imperial Eagle in Siberia. Imperial Eagle: distribution, status of populations and prospects of protection Imperial Eagle (Aquila heliaca) in Russia. Rare birds series 1: 54-61 [in Russian].

Ryabtsev, V. V. (2000) Eagles of Baikal. Irkutsk: Taltsy Press [in Russian].

Ryabtsev, V. V. (2001a) Saker Falcon in the Baikal region. Saker Falcon in Mongolia: research and conservation. Pp. 58-63 in Proceedings of the II International Conference on the Saker Falcon and Houbara Bustard, Ulaanbaatar, Mongolia 1-4 July 2000.

Ryabtsev, V. V. (2001b) The results of raptor counting in the Baikal region (Eastern Siberia) in 1999. Newsletter of the World Working Group on Birds of Prey and Owls 29-32: 23-27.

Skalon, V. N. (1934) Birds of prey in upper Angara region and their role in humans' life. Irkutsk State Anti-plague University of Siberian and Far East Region Newsletter 1932-1933 1: 55-83 [in Russian].

Sonin, V. D. (1969) Daytime birds of prey and owls in Pre-Baikal region. PhD dissertation review. Irkutsk State University [in Russian].

Sonin, V. D. and Lipin, S. I. (1980) Seasonal aspects in ecology of Imperial Eagle (Aquila heliaca) in Pre-Baikal region. Pp. ${ }^{12-24}$ in Seasonal changes of rare and extinct plants and animals [in Russian].

Snow, D. W. and Perrins, C. M. (1998) The birds of the western Palearctic, Concise Edition. New York: Oxford University Press.

Stepanyan, L. S. (1990) Conspectus of the ornithological fauna of the USSR. Moscow: Nauka Press [in Russian].

Ueta, M. and Ryabtsev, V. V. (2001) Migration routes of four juvenile Imperial Eagles Aquila heliaca from the Baikal region of eastern Russia. Bird Conserv. Int. 11: 93-99. 
Vasilchenko, A. A. (1986) Rare bird species of south-eastern Zabaikalye. Bird study in the USSR: Their protection and rational use, Theses of reports of the 1st meeting of the All-Union Ornithological Society, Leningrad, 1, 116-117 [in Russian].
Zalles, J. I. and Bildstein, K. L., eds. (200o) Raptor Watch: A global directory of raptor migration sites. Cambridge, U.K.: Birdlife International and Kempton, PA: Hawk Mountain Sanctuary (Birdlife Conservation Series No. 9).

\section{VITALIY V. RYABTSEV*}

Pribaikalsky National Park, Box 185, Irkutsk, 664049, Russia.

\section{TODD E. KATZNER $\dagger$}

National Aviary, Department of Conservation and Field Research, Allegheny Commons West, Pittsburgh, PA 15212, USA.

${ }^{*}$ Author for Russian-language correspondence.e-mail: vitryab@mail.ru or pr.bpark@inbox.ru $\dagger$ Author for English-language correspondence.e-mail: todd.katzner@aviary.org

Received 28 January 2006; revision accepted 20 July 2006 